\title{
Effect of Breeder Age on Eggshell Thickness, Surface Temperature, Hatchability and Chick Weigh
}

\section{-Author(s)}

Gualhanone A

Furlan RL

Fernandez-Alarcon MF

Macari M

Departamento de Morfologia e Fisiologia Animal

Faculdade de Ciências Agrárias e Veterinárias - campus de Jaboticabal

UNESP (Universidade Estadual Paulista)

Mail Adress
Marcos Macari
Via de Acesso Paulo D. Castellane km 5
Jaboticabal, São Paulo, Brazil
E-mail: macari@fcav.unesp.br

\section{-Keywords}

Broiler breeder, development, embryo, temperature, incubation.

\section{ABSTRACT}

Two experiments were carried out to study the effect of breeder age on incubation parameters (hatchability, eggshell thickness, egg surface temperature and chick weight). In Exp. 1, fertile eggs (30- and 60 -wk-old breeders) were incubated at three different temperatures $\left(36.8,37.8\right.$ and $\left.38.8^{\circ} \mathrm{C}\right)$. Eggshell surface temperature was measured by attaching a thermocouple to the shell and data were collected in a datalogger every ten minutes. This study was conducted according to a $3 \times 2$ factorial design (three temperatures and two breeder ages). Data revealed that eggshell surface temperature changed according to incubation temperature, with the main increase occurring between 10 and 13 days of incubation, and that the maximum increase in eggshell surface temperature was not higher than $+0.6^{\circ} \mathrm{C}$, irrespective of incubator temperature. The incubator temperature affected total incubation period and hatchability (\%) at $38.8^{\circ} \mathrm{C}$, independent of breeder age. Heavier eggs resulted in heavier chicks, irrespective of incubator temperature. In Exp 2, the eggs (30- and 60-wk-old breeders) were incubated at $37.8^{\circ} \mathrm{C}$ and eggs characteristics (weight, specific gravity, total hatchability and chicks weight) were evaluated according to a randomized experimental design. The data showed that breeder age affected eggshell thickness and chick weight (heavier eggs resulted in heavier chicks), but not specific gravity, eggshell surface temperature or hatchability. The findings of this study revealed that hatchability can be influenced by incubation temperature, but not by the breeder age. Breeder age can affect eggshell thickness, egg weight and eggshell surface temperature, but not specific gravity.

\section{INTRODUCTION}

Optimal incubation temperature is described as the temperature in which hatchability reaches its maximum and chick quality is the best (French, 1997; Decuypere \& Michels, 1992). Newly-hatched chicks can have their thermoregulatory capability affected by incubation temperature (Tzschentke \& Rumpf, 2011), which can also affect their blood hormones levels (Christensen et al., 2001) and development after hatching (Molenaar et al., 2011).

Incubator temperature in hatcheries is set between 37.5 to $37.8^{\circ} \mathrm{C}$ (Tullet, 1990), at which the embryo presents adequate development, but French (1997) reported that hatching may occur at incubator temperatures ranging from 35.0 to $40.5^{\circ} \mathrm{C}$. Sotherland et al. (1987) reported that the main increase in eggshell surface temperature is observed after D12 to D13 of incubation, mainly due to the increase in metabolic embryo heat production. At this stage internal egg temperature can increase by $1.5^{\circ} \mathrm{C}$ above incubator air temperature.

Internal egg temperature measurement implies invasive procedures 
that can affect embryo development (Holland et al., 1998). Since egg thermal conductivity is high compared with air conductivity, it is expected that internal egg temperature is slightly different from eggshell surface temperature (Lourens et al., 2005), and therefore, during embryo development, eggshell surface temperature measurements have been used to estimate embryo temperature.

A good correlation between breeder age and egg size was previously demonstrated by Raju et al. (1997). It was shown that heat exchange in heavier eggs is higher since eggshell thermal conductivity increases in larger eggs (Sotherland et al., 1987; Meijerhof \& van Beek, 1993). Breeder age had been also investigated in relation to embryo gut development (Maiorka et al., 2002) or embryo heat acclimation (Yalçin et al., 2008; Givisiez et al., 2003).

This study was carried out to investigate the effect of incubator temperature $\left(36.8,37.8\right.$ and $\left.38.8^{\circ} \mathrm{C}\right)$ and breeder age (30 and 60 weeks) on hatchability, eggshell temperature and chick development (Experiment 1), and if the characteristics of eggs produced by 30or 60-wk-old breeders interfere on hatchability and chick weight when eggs are incubated at $37.8{ }^{\circ} \mathrm{C}$ (Experiment 2).

\section{MATERIALS AND METHODS}

\section{Incubator}

Both experiments were carried out using a Petersime ${ }^{\circledR}$ incubator, Labo model, containing six blocks with $90^{\circ}$ turning every hour and with a capacity of 900 eggs. The incubator was provided with hatching space. The incubator temperature was adjusted according to dry bulb thermometer and kept constant until the end of the incubation period. The relative humidity inside the incubator machine was of approximately $55 \pm 2 \%$.

\section{Fertile eggs}

Fertile eggs (360 in Exp 1 and 900 in Exp 2) produced by $\mathrm{Cobb}^{\circledR} 500$ broiler breeders were obtained from a commercial hatchery, being half produced by 30 -week-old breeders, and the other half by 60 -weekold breeders.

\section{Eggshell surface temperature}

Eggshell surface temperature was measured by attaching a thermocouple (cooper-constant) to the shell with an adhesive tape. The thermocouple was connected to a datalogger CR10X (Campbell Sci. Inc., USA) and the temperature was recorded during the entire experimental period. Data were collected at every 10 seconds and the mean temperature at every 10 minutes was recorded.

The thermocouple had a precision of $0.05^{\circ} \mathrm{C}$ and it was calibrated by using standard mercury thermometer immersed in water.

\section{Experimental Design}

Experiment 1 was performed at three different incubation temperatures, using a total of 360 fertile eggs, with 180 eggs from each breeder age group, and 10 for each temperature, being 60 eggs from each breeder age.

Egg weight, total hatchability and chick weight were evaluated in Exp 1 according to a $3 \times 2$ factorial design (three incubation temperatures: $36.8,37.8$ and 38.80 $C$, and two breeder ages: 30 and $60 \mathrm{wk}$ ). Eggshell surface temperature data were analyzed according to a $3 \times 2 \times 19$ factorial design (three temperatures, two breeder age and 19 days of incubation). Both analyses were performed using the General Linear Models $\left(G M^{\circledR}\right.$, SAS, 2000) with different number of replicates. Means were compared by " $F$ " test and Tukey's test $(p<0.05)$.

In Exp 2 an incubation temperature of $37.8^{\circ} \mathrm{C}$ was applied and 900 fertile eggs were used (450 eggs from each breeder age). In this experiment, before incubation, 30 eggs per breeder age were used to determine egg specific gravity according to the method described by Moreng \& Avens (1990). The same egg samples were used to determine the eggshell thickness using a micrometer. The same procedure to determine eggshell thickness was used on D13 and D21 of incubationt. The experiment was conducted according to a randomized experimental design. Eggshell thickness data were analyzed according a $2 \mathrm{x}$ 3 factorial arrangement (two breeder ages and three incubation times - D0, D13 and D21), and eggshell surface temperature data were analyzed according to a 2 × 20 factorial design (two breeder ages and 20 days of incubation).

The analyses were performed using the General Linear Models $\left(G_{L}{ }^{\circledR}\right.$, SAS, 2000) with different number of replicates, and means were compared by " $F$ " test and Tukey's tests $(p<0.05)$.

\section{RESULTS}

\section{Experiment 1}

Total hatchability of eggs produced by breeders of different ages and incubated 36.8 or $37.8^{\circ} \mathrm{C}$ were 
not statistically different ( $p>0.05)$, but incubation temperature of $38.8^{\circ} \mathrm{C}$ significantly reduced $(p<0.05)$ hatchability, irrespective of breeder age (Table 1).

Table 1 - Hatchability (\%) of eggs from breeders of different ages and incubated at different incubation temperatures. Number of eggs per temperature and age $=50$.

\begin{tabular}{lccc}
\hline Breeder age & \multicolumn{3}{c}{ Incubation temperature $-{ }^{\circ} \mathrm{C}$} \\
\cline { 2 - 4 } & $36.8^{\circ} \mathrm{C}$ & $\mathbf{3 7 . 8}{ }^{\circ} \mathrm{C}$ & $38.8^{\circ} \mathrm{C}$ \\
\hline \multirow{3}{*}{30 weeks } & $78 \mathrm{Aa}{ }^{*}$ & $76 \mathrm{Aa}$ & $66 \mathrm{Ba}$ \\
60 weeks & $72 \mathrm{Aa}$ & $72 \mathrm{Aa}$ & $60 \mathrm{Ba}$ \\
\hline
\end{tabular}

* Means followed by the same capital letters in the same row are not statistically different $(p>0.05)$ and by different small letters in the same column are different $(\mathrm{p}<0.05)$. Initial mean egg weight $(\mathrm{g})$ according to breeder age (BA) and incubation temperature (IT) were: IT $-36.8^{\circ} \mathrm{C}$ : $56.8 \mathrm{~g}$ for 30 -wks and $68.4 \mathrm{~g}$ for $60 \mathrm{wks}$; IT $-37.8^{\circ} \mathrm{C}$ : 63.0 for $30 \mathrm{wks}$ and $70.9 \mathrm{~g}$ for $60 \mathrm{wks}$; IT $-38.8^{\circ} \mathrm{C}: 59.8 \mathrm{~g}$ for $30 \mathrm{wks}$ and $71.5 \mathrm{~g}$ for 60 wks.

Chick weight was affected both by incubation temperature and breeder age (Table 2).

Table 2 - Chick weight (g) of eggs produced by breeders of different ages (30 or $60 \mathrm{wks}$ ) and incubated at different incubation temperature. Each value represents mean \pm SEM. Number of birds per temperature: 30

\begin{tabular}{cc}
\hline Incubation temperature (IT) & Chick weight at hatch $(\mathbf{g})^{*}$ \\
\hline Cool $\left(36.8^{\circ} \mathrm{C}\right)$ & $47.7 \pm 0.6 \mathrm{c}^{*}$ \\
Neutral $\left(37.8^{\circ} \mathrm{C}\right)$ & $49.5 \pm 0.6 \mathrm{a}$ \\
\hline Warm $\left(38.8^{\circ} \mathrm{C}\right)$ & $48.7 \pm 0.6 \mathrm{~b}$ \\
\hline Breeder age (BA) & \\
\hline 30 weeks & $44.5 \pm 0.3 \mathrm{~b}$ \\
\hline 60 weeks & $52.8 \pm 0.2 \mathrm{a}$ \\
& $P$ values \\
\hline (IT x BA) & $<0.05$ \\
\hline
\end{tabular}

* Means in the same column followed by different small letters within each factor are different at 5\% probability level (Tukey's test).

The effect of the interaction between breeder age and incubation temperature on chick weight is shown in Table 3. Eggs from 30-wk-old breeders incubated at neutral temperature $\left(37.8^{\circ} \mathrm{C}\right)$ resulted in heavier chicks compared with the other temperatures; however, no effect $(p>0.05)$ of incubation temperature was observed on the weight of the chicks derived from the eggs of 60-wk-old breeders. As expected, irrespective of incubation temperature, chicks derived from the eggs of 60-wk-old breeders were heavier than those derived from 30-wk-old breeders $(p<0.01)$.

Figure $1(a, b$ and $c$ ) shows the time-course response of eggshell surface temperature as influenced by breeder age and incubation temperature. Interactions
Table 3 - Effect of the interaction between incubation temperature and breeder age on chick weight (g).

\begin{tabular}{lccc}
\hline Breeder age & \multicolumn{3}{c}{ Incubation temperature $-{ }^{\circ} \mathbf{C}$} \\
\cline { 2 - 4 } & $\mathbf{3 6 . 8}$ & $\mathbf{3 7 . 8}$ & $\mathbf{3 8 . 8}$ \\
\hline \multirow{3}{*}{30 week } & \multicolumn{3}{c}{ Chick weight at hatching $\mathbf{( g )}$} \\
\hline 60 week & $43.0 \mathrm{Bb}^{*}$ & $45.8 \mathrm{Ab}$ & $44.5 \mathrm{Bb}$ \\
\hline & $52.4 \mathrm{Aa}$ & $53.2 \mathrm{Aa}$ & $52.9 \mathrm{Aa}$ \\
\hline
\end{tabular}

* Means followed by capital letter in the same row and by small letters in the same column are different by Tukey's test $(p<0.05$ and $p<0.01$, respectively).
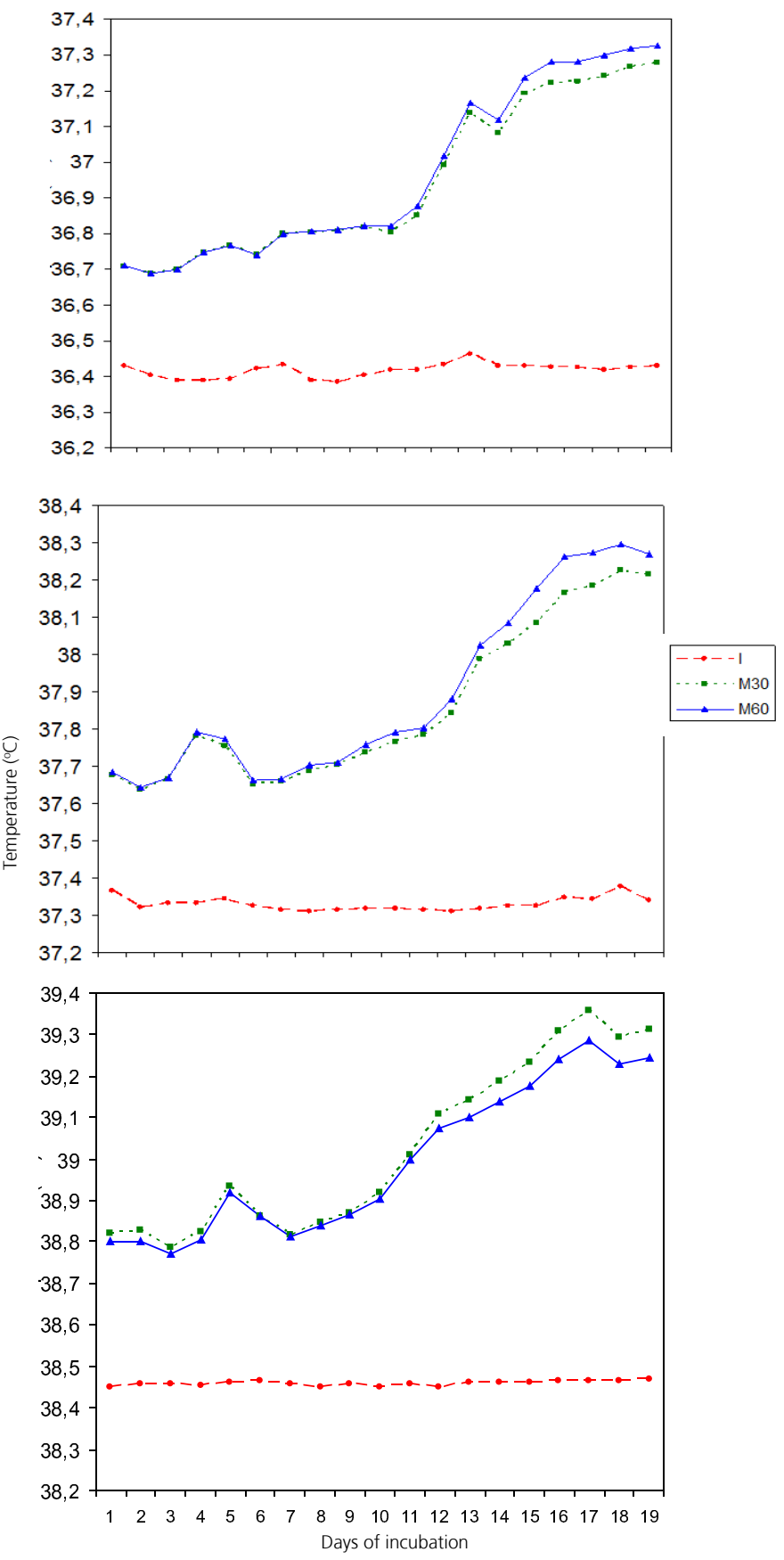

Figure 1 - Incubator (I) and eggshell temperatures of eggs from breeders of 30 (M30) and 60 (M60) weeks and incubated at 36.8 (A), $37.8(B)$ and $38.8^{\circ} \mathrm{C}(\mathrm{C})$. 
between incubation temperature and breeder age (Table 4) and incubation temperature and period of incubation (Table 5) were also observed.

Table 4-Effect of the interaction between incubation temperature and breeder age on mean eggshell surface temperature during 19 days of incubation. Each value represents mean \pm SEM.

\begin{tabular}{lccc}
\hline Breeder age & \multicolumn{3}{c}{ Incubation temperature ${ }^{\circ} \mathrm{C}$} \\
\cline { 2 - 4 } & $\mathbf{3 6 . 8}$ & $\mathbf{3 7 . 8}$ & $\mathbf{3 8 . 8}$ \\
\hline $30 \mathrm{wk}$ & $36.91 \pm 0.02 \mathrm{bC} *$ & $37.84 \pm 0.02 \mathrm{bB}$ & $39.02 \pm 0.02 \mathrm{aA}$ \\
$60 \mathrm{wk}$ & $36.93 \pm 0.02 \mathrm{aC}$ & $37.88 \pm 0.02 \mathrm{aB}$ & $38.99 \pm 0.02 \mathrm{bA}$ \\
\hline
\end{tabular}

*Means followed by different capital letters in the same row and different small letters in the same column are different by Tukey's test $(p<0.05)$.

Table 5 - Effect of the interaction between incubation temperature and days of incubation. Each value represents the daily mean eggshell surface temperature of eggs produced by 30- and 60-wkold breeders. Coefficient of variation $=0.16 \%$.

\begin{tabular}{|c|c|c|c|}
\hline \multirow{2}{*}{$\begin{array}{c}\text { Days of } \\
\text { Incubation }\end{array}$} & \multicolumn{3}{|c|}{ Incubation temperature $\left({ }^{\circ} \mathrm{C}\right)$} \\
\hline & 36.8 & 37.8 & 38.8 \\
\hline 01 & $36.71 \mathrm{cHIJ*}$ & $37.68 \mathrm{bHI}$ & $38.81 \mathrm{aHI}$ \\
\hline 02 & $36.69 c J$ & $37.64 \mathrm{bl}$ & $38.81 \mathrm{aHI}$ \\
\hline 03 & $36.70 \mathrm{clJ}$ & $37.67 \mathrm{bl}$ & 38.78al \\
\hline 04 & $36.75 \mathrm{cFGHIJ}$ & $37.79 b \mathrm{~b}$ & $38.81 \mathrm{aHI}$ \\
\hline 05 & $36.77 \mathrm{cFGHI}$ & 37.77bEFG & $38.93 \mathrm{aF}$ \\
\hline 06 & $36.74 c G H I J$ & $37.66 \mathrm{bl}$ & 38.86aFGH \\
\hline 07 & $36.80 \mathrm{cEFG}$ & $37.66 \mathrm{bl}$ & $38.82 \mathrm{aHI}$ \\
\hline 08 & $36.81 \mathrm{cEFG}$ & 37.70bFGHI & $38.84 \mathrm{aGHI}$ \\
\hline 09 & $36.81 \mathrm{cEFG}$ & 37.71bFGHI & 38.87aFGH \\
\hline 10 & 36.82cEF & 37.75bEFGH & 38.91aFG \\
\hline 11 & $36.81 \mathrm{cEF}$ & 37.78bEF & $39.01 \mathrm{aE}$ \\
\hline 12 & $36.86 \mathrm{cE}$ & $37.79 \mathrm{bD}$ & $39.09 \mathrm{aD}$ \\
\hline 13 & $37.01 \mathrm{cD}$ & $37.86 \mathrm{bD}$ & 39.12aD \\
\hline 14 & $37.15 c B C$ & $38.01 b c$ & $39.17 \mathrm{aCD}$ \\
\hline 15 & $37.10 \mathrm{cC}$ & $38.06 \mathrm{bC}$ & $39.21 \mathrm{aBC}$ \\
\hline 16 & $37.21 \mathrm{CAB}$ & $38.13 \mathrm{bB}$ & $39.28 \mathrm{aAB}$ \\
\hline 17 & $37.25 \mathrm{CA}$ & $38.22 \mathrm{bA}$ & $39.32 \mathrm{aA}$ \\
\hline 18 & $37.25 \mathrm{CA}$ & $38.23 \mathrm{bA}$ & $39.26 \mathrm{aAB}$ \\
\hline 19 & $37.27 \mathrm{CA}$ & $38.26 \mathrm{bA}$ & $39.28 a A B$ \\
\hline
\end{tabular}

* Means followed by different capital letters in the same row and different small letters in the same column are different Tukey's test $(p<0.05)$.
The results revealed that mean eggshell surface temperature was slightly higher in the eggs from 60-wk-old breeders when incubated at 36.8 and 37.8 ${ }^{\circ} \mathrm{C}$, but when incubation temperature was $38.8{ }^{\circ} \mathrm{C}$, eggshell temperature was higher in the eggs of 30-wkold breeders.

A sharp increase in eggshell temperature on D12 in eggs incubated at 36.8 and $37.8^{\circ} \mathrm{C}$ and on D10 for eggs incubated at $38.8^{\circ} \mathrm{C}$ was also observed.

\section{Experiment 2}

In this experiment, eggs were incubated at the same temperature $\left(37.8^{\circ} \mathrm{C}\right)$ and the results are shown in Table 6 . The findings revealed that there was no significant statistical difference $(p>0.05)$ in hatchability or egg specific gravity between breeder ages, and, as expected, heavier eggs (60-wk-old breeders) resulted heavier chicks $(p<0.01)$.

Figure 2 shows the time course response of eggshell surface temperature during the incubation period of eggs produced by breeders of both ages at the same incubation temperature $\left(37.8^{\circ} \mathrm{C}\right)$. Breeder age did not affect eggshell temperature ( $p>0.05)$, but, as expected, it changed according to the incubation period. A sharp increase in eggshell temperature was again observed after D12, irrespective of breeder age.

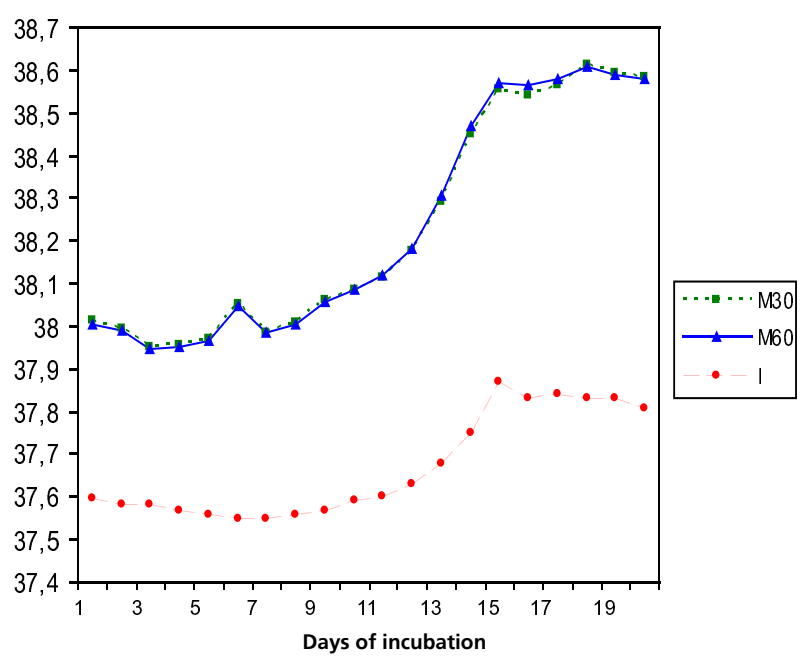

Figure 2 - Incubator (I) and eggshell temperatures of eggs from breeder of 30 (M30) and 60 (M60) weeks of age which were incubated at $37.8^{\circ} \mathrm{C}$

Table 6 - Egg weight (g), specific gravity, total hatchability (\%) and chick weight $(\mathrm{g})$. Each value represents mean \pm SEM. Number of eggs per breeder age $=450$.

\begin{tabular}{ccccc}
\hline Breeder age (wk) & Egg weight (g) & Specific gravity & Total hatchability (\%) & Chicks weight (g) \\
\hline $30 w k$ & $59.48 \pm 0.57 b^{*}$ & $1.084 \pm 0.006 a$ & $74 a$ & $44.45 \pm 2.70 a$ \\
60 wk & $70.39 \pm 0.46 \mathrm{a}$ & $1.082 \pm 0.004 \mathrm{a}$ & $71 \mathrm{a}$ & $52.12 \pm 3.66 \mathrm{~b}$ \\
\hline
\end{tabular}

\footnotetext{
* Means followed with the same small letters in the column are not different by Tukey's test ( $p>0.05)$.
} 
Eggshell thickness was influenced by breeder age, with young breeders producing eggs with thicker eggshells (0.376 vs. $0.365 \mathrm{~mm} ; \mathrm{p}<0.01)$. On the other hand, during incubation, shell thickness was reduced irrespective of breeder age (mean value at $\mathrm{D} 0=0.392$ $\mathrm{mm}, \mathrm{D} 13=0.376 \mathrm{~mm}$ and D21 $=0.343 \mathrm{~mm} ; \mathrm{p}<0.01$ ).

\section{DISCUSSION}

The findings of this study showed that heavier eggs resulted in heavier chicks, as expected, corroborating several authors that reported a positive correlation between egg weight and chick weight (Shanawany, 1984; Raju et al., 1997). On the other hand, egg weight increases with the breeder age (Suarez et al., 1997; Novo et al., 1997; Lourenço da Silva, 1994; North \& Bell, 1990; Sooncharenying \& Edwards, 1989); thus, older breeders with heavier eggs produced heavier chicks, irrespective of incubation temperature. Chick weight is an important factor in broiler growth, since it was reported that there is a positive and strong correlation between chick weight at hatch and broiler market weight (42 to 45 days of age) (Raju et al., 1997; Proudfoot \& Hulan, 1981).

Hatchability was significantly lower in the eggs incubated at high ambient temperature $\left(38.8^{\circ} \mathrm{C}\right)$, but there was no influence of breeder age on hatchability. Heier \& Jarp (2001) reported that mean hatchability increased in eggs from breeders in their first production cycle (28 to 36 wk), decreasing afterwards. The lack of differences in hatchability observed in present study may be related to correct egg management, the short interval between lay and incubation (Roque \& Soares, 1994) and eggshell quality (Berrang et al., 1998). Bennett (1992) reported reduced hatchability in eggs from old breeders; however, in that study, the specific gravity of about $90 \%$ of the eggs of 55 -wk-old breeders waslower than 1.080 (low eggshell quality). In our study, specific gravity was not statistically different between breeder ages; however, it was higher than 1.080, an indication of good eggshell quality (Berrang et al., 1998; Lourenço da Silva, 1994; Bennett, 1992). It must be noted that aging does not necessarily impair eggshell quality; in fact, hatchability may still be high in eggs from old breeders (Berrang et al., 1998; North \& Bell, 1990). Hamidu et al. (2007), studying eggshell conductance, reported that neither breeder strain or parent flock age affected this parameter.

Eggshell thickness was reduced during the incubation period, independently of breeder age. Lourenço da Silva (1994) stated that the embryo can use about $47 \%$ of the eggshell mass during the incubation period, since it provides approximately $80 \%$ of the calcium for skeleton formation after D10 (Peebles \& Brake, 1985). In the present study, the most striking difference in eggshell thickness was observed on D13, which is consistent with the findings of Peebles et al. (2001), who reported a decrease in eggshell weight of eggs produced by 27- and 36-wk-old breeders after D12.

Eggshell surface temperature changed as a function of incubation temperature and breeder age. The effect of breeder age on eggshell temperature can be partly explained by the fact that embryos from larger eggs have higher metabolic heat production, but their relative surface for heat exchange is lower (Meijerhof \& van Beek, 1993; Hamidu et al., 2007). On the other hand, due their size, heat exchange may be reduced among eggs in the incubator. At all incubation temperatures, eggshell temperature increased the most between 10 and 13 days of incubation, which is consistent with the findings of Nichelmann et al. (1998) and Decuypere et al. (1979) that embryo heat production increases during the second period of incubation (after D12). Romijin \& Lokhorst (1960) also reported that at the beginning of incubation period evaporative heat loss is higher than the metabolic heat production, and therefore, the egg gains heat; however, during the second incubation period (D12 onwards) embryo metabolic heat production is much higher than its evaporative heat loss, thereby increasing eggshell surface temperature.

In conclusion, the findings of the present study showed that hatchability can be influenced by incubation temperature, but not by breeder age. Breeder age can also affects eggshell thickness, egg weight, and eggshell surface temperature, but not specific gravity.

\section{REFERENCES}

Bennett CB. The influence of shell thickness on hatchability in commercial broiler breeder flocks. Journal of Applied Poultry Research 1992;1:61-65.

Berrang ME, Frank JF, Buhr RJ, Bailey JS, Cox NA, Mauldin J. Eggshell characteristics and penetration by Salmonella through the productive life of a broiler breeder flock. Poultry Science 1998; 77:1446-1450.

Christensen VL, McMurtry JP, Donaldson WE, Nestor KE. Incubation temperature affects plasma insulin-like growth factors in embryos from selected lines of turkeys. Poultry Science 2001; 80:949-954.

Decuypere E, Nouwen EJ, Kuhn ER, Geers R, Michels H. lodohormones in the serum of chicks embryos and post-hatching chickens as influenced by incubation temperatures. Relationship with the hatching process and thermogenesis. Annales de Biologie Animale Biochemie Biophysique 1979; 19:1713-1723. 
Decuypere $\mathrm{E}$, Michels $\mathrm{H}$. Incubation temperature as a management tool: a review. World's Poultry Science Journal 1992; 48:28-38.

French NA. Modelling incubation temperature: the effects of incubator design, embryonic development, and egg size. Poultry Science 1997; 76: 124-133.

Givisiez PEN, Furlan RL, Malheiros EB, Macari M. Incubation and rearing temperature effects on $\mathrm{Hsp} 70$ levels and heat stress response in broilers. Canadian Journal of Animal Science 2003; 83:213-220.

Hamidu JA, Fasenko GM, Feddes JJR, O'Dea EE, Ouellette CA, Wineland MJ, Christensen VL. The effect of broiler breeder genetic strain and parent flock age on eggshell conductance and embryonic metabolism. Poultry Science 2007; 86:2420-2432.

Heier BT, Jarp J. An epidemiological study of the hatchability in broiler breeder flocks. Poultry Science 2001; 80:1132-1138.

Holland S, Hochel J, Burmeister A, Janke O, Nickelman M. A method for measuring deep body temperature in avian embryos. Journal of Thermal Biology 1998; 23:123-129.

Lorenço da Silva PR. Influência do manejo na qualidade da casca dos ovos de reprodutoras pesadas. Anais da Conferência Apinco de Ciência e Tecnologia Avícolas; 1994; Santos,São Paulo. Brasil. Campinas: FACTA; 1994. p.23-34.

Lourens A, Van den Brand H, Meijerhof R, Kemp B. Effect of Eggshell Temperature During Incubation on Embryo Development, Hatchability, and Posthatch Development. Poultry Science 2005; 84:914-920.

Maiorka A, Boleli IC, Macari M. Desenvolvimento e reparo da mucosa intestinal. In: Macari M, Furlan RL, Gonzáles E. Fisiologia aviária aplicada a frangos de corte. Jaboticabal: Funep; 2002. p.113-123.

Meijerhof R, van Beek G. Mathematical modeling of temperature and moisture loss of hatching eggs. Journal of Theoretical Biology 1993; 165: 27-41.

Molenaar R, Hulet R, Meijerhof R, Maatjens CM, Kemp B, Van den Brand $\mathrm{H}$. High eggshell temperatures during incubation decrease growth performance and increase the incidence of ascites in broiler chickens. Poultry Science 2011; 90:624-632.

Moreng RE, Avens JS. Ciência e produção de aves. São Paulo: Roca; 1990. p.355.

Nichelmann M, Burmeister A, Janke O, Hochel J, Tzchentke B. Avian embryonic thermoregulation: role Q10 in interpretation of endothermic reactions. Journal of Thermal Biology 1998; 23:369-376.

North MO, Bell DD. Commercial chicken production Manual. NewYork: Chapman \& Hall; 1990. p. 103-134.

Novo RP, Gama LT, Chaveiro Soares M. Effects of oviposition time, hen age, and extra dietary calcium on egg characteristics and hatchability. Journal of Applied Poultry Research 1997; 6:335-343.

Peebles ED, Brake J. Relationship of eggshell porosity to stage of embryonic development in broiler breeders. Poultry Science 1985; 64:2388-2391.

Peebles ED, Doyle SM, Zumwalt CD, Gerard PD, Latour MA, Boyle CR, Smith TW. Breeder age influence embryogenesis in broiler hatching eggs. Poultry Science 2001; 80:272-277.

Proudfoot FG, Hulan HW. The influence of hatching egg size on the subsequent performance of broiler chickens. Poultry Science 1981; 60: 2167-2170.
Raju MVLN, Chawak MM, Praharaj NK, Rao SVR, Mishra SK. Interrelationships among egg weight, hatchability, chick weight, post-hatch performance and rearing method in broiler breeders. Indian Journal of Animal Sciences $1997 ; 67: 48-50$

Romijin C, Lokhorst W. Foetal heat production in the fowl. Journal of Physiology 1960; 150:239-249.

Roque L, Soares MC. Effects of eggshell quality and broiler breeder age on hatchability. Poultry Science 1994; 73:1838-1845.

SAS Institute. User's guide: statistics. Cary; 2000.

Shanawany MM. Inter-relationship between egg weight, parental age and embryonic development. British Poultry Science 1984; 25:449-455.

Sooncharenying S, Edwards HM. Modelling the relationship of egg weight, specific gravity, shell calcium, and shell thickness. British Poultry Science 1989; 30:623-631.

Suarez ME, Wilson HR, Mather FB, Wilcox CJ, McPherson BN. Effect of strain and age on the broiler breeder female on incubation time and chick weight. Poultry Science 1997; 76:1029-1036.

Sotherland PR, Spotila TR, Paganelli CV. Avian eggs: barriers to the exchange of heat and mass. Journal of Experimental Zoology 1987; 1: 81-86. Suppl

Tullet SG. Science and art of incubation. Poultry Science 1990; 69:1-15.

Tzschentke B, Rumpf M. Embryonic development of endothermy. Respiratory Physiology \& Neurobiology 2011; 178:97-107.

Yalçin S, Çabuk M, Bruggeman V, Babacanoglu E, Buyse J, Decuypere E, Siegel PB. Acclimation to heat during incubation: 3. Body weight, cloacal temperatures, and blood acid-base balance in broilers exposed to daily high temperatures. Poultry Science 2008; 87:2671-2677. 